\title{
Retraction: Probucol suppresses human glioma cell proliferation in vitro via ROS production and LKB1- AMPK activation
}

Yong-sheng JIANG, Jing-an LEI, Fang FENG, Qi-ming LIANG, Fu-rong WANG

Acta Pharmacol Sin 2014; 35: 1556-65.

A retraction of Asian Pacific Journal of Cancer Prevention (Asian Pac J Cancer Prev 2017 Nov 24; 18: 2895) was brought to the attention of the editors of Acta Pharmacologica Sinica. After serious investigation, the editors confirmed that there was duplication and contacted with the authors. The authors acknowledged that the Western blottings in Figure 1D and 1E of the above article were mistakenly used. The authors agreed to retract the article to maintain the integrity of the scientific record.

Acta Pharmacologica Sinica (2018) 39: 328; doi: 10.1038/aps.2018.2 